\title{
ANALISIS KOMPETENSI GURU MADRASAH IBTIDAIYAH DALAM PEMANFAATAN TEKNOLOGI INFORMASI DAN KOMUNIKASI PADA PEMBELAJARAN (STUDI KASUS PADA MIN 4 LANGKAT)
}

\author{
Marinasari Fithry Hasibuan
}

Balai Diklat Keagamaan Medan JI. TB. Simatupang No. 122 Medan Telp. (061)8456256

E-mail: marinasari.hasibuan@gmail.com Naskah diterima: 12 Nopember 2021 Naskah Direvisi: 12-20 Oktober 2021 Naskah disetujui: 3 Desember 2021 Website Jurnal:

\begin{abstract}
ABSTRAK
Penelitian ini memnbahas tentang kompetensi guru Madrasah Ibtidaiyah dalam pemanfaatan teknologi dan Informasi pada pembelajaran dengan indikator kompetensi adalah kurikulum pelatihan TIK bagi guru madrasah yang disusun Pusdiklat Teknis Pendidikan dan Keagamaan Jakarta. Penelitian ini bertujuan untuk mengetahui kompetensi dan permasalahan guru madrasah Ibtidaiyah dalam pemanfaatan teknologi informasi dan komunikasi pada pembelajaran daring di masa covid 19 ini. Penelitian ini menggunakan studi kasus dengan responden seluruh guru pada MIN 4 Langkat. Metode penelitian yang digunakan dalam peenlitian ini adalah metode survey dengan menggunakan angket yang di share melalui google form. Analisis data yang digunakan adalah analisis deskriptif yang menggambarkan kualifikasi kompetensi guru dalamn pemanfaatan TIK menjadi empat tingkatan yaitu sangat rendah, rendah, sedang dan tinggi. Dari hasil data yang telah di analisis di temukan bahwa kompetensi guru dalam TIK sangat rendah pada kemampuan penggunaan dan pemanfaatan aplikasi yaitu sebesar $52 \%$. Selanjutnya indikator sangat rendah terdapat pada aspek pengalaman mengikuti pelatihan sebesar $57 \%$. Hal ini menunjukkan bahwa kegiatan pelatihan adalah faktor yang paling dominan menjadi penyebab rendahnya kompetensi guru dalam pemanfaatan TIK pada pembelajaran dan oleh karena itu menjadi solusi yang paling efektif untuk mengatasi.
\end{abstract}

Kata kunci: Kemampuan, Pendidik, Pembelajaran Daring

\begin{abstract}
This study discusses the competence of Madrasah Ibtidaiyah teachers in the use of technology and information in learning with competency indicators being the ICT training curriculum for madrasa teachers compiled by the Jakarta Education and Religious Technical Training Center. This study aims to determine the competence and problems of Islamic boarding school teachers in the use of information and communication technology in online learning during this covid 19 period. This study uses a case study with all teachers as respondents at MIN 4 Langkat. The research method used in this research is a survey method using a questionnaire that is shared via a google form. Analysis of the data used is a descriptive analysis that describes the qualifications of teacher competence in the use of ICT into four levels, namely very low, low, medium, and high. From the results of the data that has been analyzed, it was found that the competence of teachers in ICT is very low in the ability to use and utilize applications, which is 52\%. Furthermore, a very low indicator is found in the experience aspect of
\end{abstract}


participating in training at 57\%. This shows that training activities are the most dominant factor causing the low competence of teachers in the use of ICT in learning and therefore the most effective solution to overcome them.

Keywords: Ability, Educator, Online Learning

\section{PENDAHULUAN}

Penelitian ini membahas tentang kompetensi guru dalam pemanfaatan teknologi informasi dan komunikasi pada pembelajaran sebagai salah satu dari kompetensi paedagogik yang wajib dimiliki oleh seorang pendidik dan tenaga kependidikan lainnya. (Permendiknas, 2021) Penelitian ini bertujuan untuk mengetahui kompetensi guru madrasah khususnya guru Madrasah Ibtidiayah. Penelitian ini sangat penting dilakukan karena sesuai dengan tuntutan pembelajaran abad 21 yang berbasis 4C yaitu Critical Thinking, Creatifity, Collaboration dan Comunication. (Kebudayaan, 2013) Selain itu, munculnya wabah Covid-19, semakin menuntut para guru terampil menerapkan TIK karena proses pembelajaran sudah berbasis online atau isitlah yang digunakan saat ini disebut dengan pembelajaran daring. (Isradini, dkk, 2020).

Penelitian tentang kompetensi guru dalam pemanfaatan teknologi informasi dan komunikasi pada pembelajaran sudah banyak dilakukan. Penelitian terkait dengan kompetensi guru dalam pemanfaatan teknologi informasi dan komunikasi telah dilakukan oleh Karjani yang mengatakan bahwa sebelum kegiatan in house training di laksanakan, guru guru di SD Negeri 1 Giriwoyo belum mampu mengoprasionalkan komputer. Tetapi setelah dilakukan penerapan In Hause Traning dengan dua siklus maka terdapat peningkatan kompetensi guru SD Negeri I Giriwoyo dalam melaksanakan pembelajaran Berbasis Multi Media Interaktif. (Karjani, 2019). Selanjutnya Yunitasari mengatakan bahwa untuk meningkatkan penguasaan guru terhadap media pembelajaran berbasis teknologi informasi dan komunikasi maka diperlukan pelatihan -pelatihan terkait dengan teknologi informasi dan komunikasi. (Yunitasari, 2016). Pendapat tersebut juga dikuatkan oleh Idris yang mengatakan bahwa untuk meningkatkan keterampilan guru dalam TIK, maka guru perlu diberikan pelatihan khusus tentang penggunaan TIK. (Idris , Fauzan, 2018 (2007, 2007) (2007, 2007)).

Namun sebagai media pembelajaran, TIK memiliki beberapa kekurangan yang harus diantisipasi dalam dunia pendidikan yaitu sensor terhadap informasi yang tidak bermanfaat dan dapat merusak moral peserta didik serta akses jaringan internet yang tidak merata yang memunculkan kesenjangan digital antar siswa atau sekolah. (Suryadi, 2015).

Adapun faktor lain yang dapat menghambat pemanfaatan TIK dalam pembelajaran adalah kurangnya inisiatif guru untuk mengembangkan potensi dirinya secara mandiri serta kurangnya fasilitas yang disedikan oleh satuan pendidikan tempat guru bertugas. (Siahaan, 2015). Namun di masa pandemi Covid-19 ini pemanfaatan teknologi informasi dan komunikasi dalam pembelajaran sudah tidak dapat dihindari lagi karena pembelajaran sudah dilakukan secara daring / online. ( Anugrahana, 2020).

Banyak jenis media pembelajaran yang dapat di manfaatkan oleh guru terkait dengan pembelajaran daring diantaranya adalah Google Classroom, Study Room, Zoom, Video Fusion, dan lain-lain. (Puspita, 2019) 
Hal ini sangat sejalan dengan Kurikulum pelatihan Teknologi Informasi Komunkasi bagi guru madrasah yang disusun oleh Pusdiklat Teknis Pendidikan Keagamaan Jakarta Tahun 2021. Untuk itu penelitian ini sangat penting dilakukan sebagai gambaran umum kesiapan kompetensi guru madrasah khususnya guru pada Madrasah Ibtidaiyah dalam pembelajaran daring, mengingat karena berdasarkan data yang diperoleh dari Website resmi Kementerian Agama Propinsi Suimatera Utara Tahun 2020, jumlah guru Madrasah Ibtidaiyah baik Negeri Maupun Swasta berjumlah 9.642 orang. (Propinsi Sumatera Utara, 2020)

Sementara pelatihan TIK bagi guru madrasah yang dilaksanakan oleh Balai Diklat Keagamaan Medan Tahun 2021 hanya berjumlah tujuh Angkatan dan setiap Angkatan hanya terdiri dari 30 orang peserta. Berarti hanya 210 orang peserta yang dapat di akomodir oleh Balai Diklat Keagamaan Medan dalam pelatihan teknologi inrofmasi dan komunikasi. Jika dibuat dalam bentuk persentasi, maka perbandingan jumlah alumni pelatihan TIK tahun 2021 pada Balai Diklat Keagamaan Medan dengan jumlah seluruh guru madrasah di Propinsi Sumatera utara adalah sebesar 2,17\%.

Situasi ini tentu sangat
memprihantinkan
penelitian yang telah dilakukan oleh beberapa peneliti terdahulu yang menyatakan bahwa salah satu factor penyebab rendahnya kompetensi guru dalam pemanfaatan TIK pada pembelajaran adalah karena kurangnya pelatihanpelatihan yang di adakan baik oleh lembaga pelatihan resmi yang telah ditunjuk oleh pemerintah maupun pelatihan-pelatihan yang diselenggarakan oleh Lembaga pendidikan tempat guru-guru tersebut bertugas.
Penelitian terkait dengan rendahhya kompetensi guru madrasah dalam pemanfaatan teknologi informasi dan komunikasi juga telah dilakukan oleh Rupiah yang menyatakan bahwa WhatsApp masih dominan digunakan oleh guru dalam menyampaikan materi pembelajaran maupun dalam mengumpulkan tugas siswa karena sangat mudah mengoprasionalkannya. (Rupiah, 2021). Penelitian yang sama juga dilakukan oleh menyatakan bahwa WhatsApp menjadi pilihan favorit guru dalam menyampaikan materi pelajaran di masa pandemi Covid 19. (Rahmawati, 2020). Maka penelitian terkait dengan kompetensi guru madrasah dalam pemanfaatan TIK pada pembelajaran telah dilakukan oleh Mulyana. Hasil penelitiannya menjelaskan bahwa kompetensi guru Madrasah Aliyah Negeri I Bandung Barat dalam pemanfaatan TIK pada pembelajaran khususnya guru mata pelajaran agama masih sangat terbatas. Hal ini disebabkan karena guru mata pelajaran umum lebih sering mengikuti pelatihan TIK daripada guru mata pelajaran agama. (Mulyana, 2019).

Penelitian lainnya juga dilakukan oleh Imam Makruf. .Hasil penelitiannya menyatakan bahwa penggunaan media dan sumber belajar berbasis TIK guru mata pelajaran Bahasa Arab di Madrasah Aliyah Kabupaten Sukoharjo pada umumnya merupakan media yang dibuat oleh guru sendiri tetapi masih dalam bentuk power point. (Makruf, 2020)

Penelitian selanjutnya diteliti oleh Rahmadayani dkk. Hasil penelitian itu menyatakan bahwa guru MIN 2 Banda Aceh belum memanfaatkan teknologi dalam pembelajaran. (Rahmadani, dkk, 2021). Di dalam penelitian ini, yang dimaksud dengan permasalahan kompetensi guru Madrasah Ibtidaiyah terkait dengan kompetensi dalam pemanfaatan teknologi informasi dan 
komunikasi pada pembelajaran adalah kompetensi pemanfaatan teknologi komunikasi dan informasi yang sesuai dengan tuntutan kurikulum Pusdiklat Teknis Keagamaan tentang pelatihan TIK bagi guru tahun 2021 yang terdiri dari pembuatan konten video interaktif dalam pembelajaran, pembuatan presentasi menarik menggunakan aplikasi popular, pembuatan kelas online menggunakan aplikasi populer dan pembuatan blog sebagai portofolio menggunakan aplikasi popular. (Keagamaan, 2021)

Temuan penelitian terkait dengan kompetensi TIK guru sebagaimana yang telah dikemukakan di atas pada umum menyatakan bahwa upaya untuk meningkatkan kompetensi TIK bagi guru adalah dengan memperbanyak jumlah pelatihan-pelatihan terkait teknologiteknologi informasi baik yang diselenggarakan oleh lembaga pemerintah maupun oleh lembaga-lembaga pendidikan pada satuan pendidikan.

Namun, penelitian terdahulu belum ada yang membahas tentang kompetensi guru madrasah khususnya Madrasah Ibtidaiyah yang ada di Kabupaten Langkat dan belum membahas tentang kompetensi guru terkait dengan kurikulum pelatihan TIK yang disusun oleh Pusdiklat Teknis Pendidikan Keagamaan Jakarta.

\section{METODOLOGI PENELITIAN}

Penelitian ini menggunakan metode survey dengan instrumen skala likert. Option yang digunakan dalam skala likert terdiri dari empat option yaitu tidak pernah, pernah, jarang dan selalu. Pilihan Option Skala likert ini nantinya akan mendeskripsikan tingkat kompetensi guru dalam TIK yaitu untuk pilihan option tidak pernah, maka kompetensi TIK guru di kualifikasikan sangat rendah. Untuk option pernah dikualifikasikan rendah, untuk option jarang kompetensi guru dalam TIK dikualifikasikan sedang dan untuk option selalu maka kompetensi guru dalam TIK dikualifikasikan tinggi. Adapun materi survey yang dijadikan sebagai instrumen adalah seluruh lingkup materi yang ada pada kurikulum pelatihan TIK bagi guru madrasah yang terdiri dari kompetensi guru mengoprasionalkan video pembelajaran, kompetensi guru dalam mengoprasionalkan aplikasi prezzy, kompetensi guru dalam mengoprasionalkan google classroom dan kompetensi guru dalam mengoprasionalkan blog. Adapun indikator dari masing-masing aspek kompetensi terdiri dari pengenalan terhadap aplikasi, kemampuan menggunakan aplikasi, kemampuan memanfaatkan aplikasi dan pengalaman dalam pelatihan terhadap aplikasi. Dari hasil survey, dapat di diskripsikan aspek kompetensi yang paling dominan sudah dikuasai guru dan aspek kompetensi yang dominan belum atau kurang dikuasai guru terkait dengan empat kompetensi tersebut.

Penyebaran instrumen survey ini dilakukan dengan menggunakan media google form. Adapun yang menjadi responden di dalam penelitian ini adalah seluruh guru pada MIN 4 Langkat yang berjumlah 24 orang.

Hasil analisis deskriptif dalam penelitian ini masih sangat sederhana karena hanya menggunakan satu jenis instrumen angket. (tidak melakuan triangulasi dengan jenis instrument peneltian lainnya seperti quisioner, observasi, wawancara dan dokumentasi). Hal ini disebabkan karena keterbatasan waktu dan biaya sehingga untuk penyempurnaan hasil peneletian ini di rencanakan akan dilakukan penelitian lanjutan (resaearch and development).

\section{HASIL DAN PEMBAHASAN}

Penyebaran survey yang dilakukan dalam penelitian ini dilakukan melalui media google form dengan jumlah responden sebanyak 24 orang. Namun data yang 
terkumpul hanya berjumlah 22 orang. Dari hasil olah data yang telah dilakukan, maka dapat di paparkan kompetensi guru MIN 4 Langkat dalam pemanfaatan teknologi informasi dan komunikasi pada pembelajaran dapat dilihat pada tabel di bawah ini

Tabel I. Data kompetensi guru dilihat dari keseluruhan butir pertanyaan

\begin{tabular}{|c|c|c|c|c|}
\hline No & Option & $\begin{array}{c}\text { Skor } \\
\text { jawaban }\end{array}$ & Persentasi & Kualifikasi \\
\hline 1 & Tidak Pernah & 394 & $46 \%$ & Sangat Rendah \\
\hline 2 & Pernah & 229 & $28 \%$ & Rendah \\
\hline 3 & Jarang & 126 & $15 \%$ & Sedang \\
\hline 4. & Selalu & 91 & $11 \%$ & Tinggi \\
\hline
\end{tabular}

Tabel 2. Data kompetensi guru dilihat dari aspek materi pemanfaatan blog dalam pembelajaran

\begin{tabular}{|c|c|c|c|c|}
\hline No & Option & Skor Jawaban & Persentasi & Kualifikasi \\
\hline 1 & Tidak Pernah & 118 & $50 \%$ & Sangat Rendah \\
\hline 2 & Pernah & 66 & $27 \%$ & Rendah \\
\hline 3 & Jarang & 28 & $13 \%$ & Sedang \\
\hline 4. & Selalu & 23 & $10 \%$ & Tinggi \\
\hline
\end{tabular}

Tabel 3. Data kompetensi guru dilihat dari aspek materi pemanfaatan Google Classroom dalam pembelajaran

\begin{tabular}{|c|c|c|c|c|}
\hline No & Option & Skor jawaban & Persentasi & Kualifikasi \\
\hline 1 & Tidak Pernah & 62 & $28 \%$ & Sangat Rendah \\
\hline 2 & Pernah & 88 & $40 \%$ & Rendah \\
\hline 3 & Jarang & 49 & $22 \%$ & Sedang \\
\hline 4. & Selalu & 23 & $10 \%$ & Tinggi \\
\hline
\end{tabular}

Tabel 4. Data kompetensi guru dilihat dari aspek materi pemanfaatan video dalam pembelajaran

\begin{tabular}{|c|c|c|c|c|}
\hline No & Option & Skor Jawaban & Persentasi & Kualifikasi \\
\hline 1 & Tidak Pernah & 124 & $47 \%$ & Sangat Rendah \\
\hline 2 & Pernah & 71 & $27 \%$ & Rendah \\
\hline 3 & Jarang & 31 & $12 \%$ & Sedang \\
\hline 4. & Selalu & 38 & $14 \%$ & Tinggi \\
\hline
\end{tabular}


Tabel 5. Data kompetensi guru dilihat dari aspek materi pemanfaatan aplikasi prezzy sebagai bahan presentasi menarik dalam pembelajaran

\begin{tabular}{|c|c|c|c|c|}
\hline No & Option & Skor Jawaban & Persentasi & Kualifikasi \\
\hline 1 & Tidak Pernah & 90 & $68 \%$ & Sangat Rendah \\
\hline 2 & Pernah & 13 & $10 \%$ & Rendah \\
\hline 3 & Jarang & 22 & $17 \%$ & Sedang \\
\hline 4. & Selalu & 7 & $5 \%$ & Tinggi \\
\hline
\end{tabular}

Kemudian, berdasarkan indikator instrumen sebagaimana yang telah dipaparkan di atas, maka kompetensi guru dalam pemanfaatan teknologi informasi dan komunikasi dapat dilihat pada tabel di bawah ini:

Tabel 6. Kompetensi guru terkait dengan pemahaman guru terhadap aplikasi

\begin{tabular}{|c|c|c|c|c|}
\hline No & Option & Skor jawaban & Persentasi & Kualifikasi \\
\hline 1 & Tidak Pernah & 26 & $25 \%$ & Sangat Rendah \\
\hline 2 & Pernah & 39 & $46 \%$ & Rendah \\
\hline 3 & Jarang & 8 & $11 \%$ & Sedang \\
\hline 4. & Selalu & 15 & $18 \%$ & Tinggi \\
\hline
\end{tabular}

Tabel 7. Kompetensi guru dilihat dari kemampuan menggunakan aplikasi

\begin{tabular}{|c|c|c|c|c|}
\hline No & Option & Skor Jawaban & Persentasi & Kualifikasi \\
\hline 1 & Tidak Pernah & 69 & $52 \%$ & Sangat Rendah \\
\hline 2 & Pernah & 30 & $23 \%$ & Rendah \\
\hline 3 & Jarang & 25 & $19 \%$ & Sedang \\
\hline 4. & Selalu & 8 & $6 \%$ & Tinggi \\
\hline
\end{tabular}

Tabel 8. Kompetensi guru dilihat dari kemampuan memanfaatkan aplikasi

\begin{tabular}{|c|c|c|c|c|}
\hline No & Option & Skor Jawaban & Persentasi & Kualifikasi \\
\hline 1 & Tidak Pernah & 126 & $52 \%$ & Sangat Rendah \\
\hline 2 & Pernah & 59 & $24 \%$ & Rendah \\
\hline 3 & Jarang & 41 & $17 \%$ & Sedang \\
\hline 4. & Selalu & 16 & $7 \%$ & Tinggi \\
\hline
\end{tabular}


Tabel 9. Kompetensi guru dilihat dari pengalaman pelatihan

\begin{tabular}{|c|c|c|c|c|}
\hline No & Option & Skor & Persentasi & Kualifikasi \\
\hline 1 & Tidak Pernah & 125 & $57 \%$ & Sangat Rendah \\
\hline 2 & Pernah & 46 & $21 \%$ & Rendah \\
\hline 3 & Jarang & 35 & $16 \%$ & Sedang \\
\hline 4. & Selalu & 14 & $6 \%$ & Tinggi \\
\hline
\end{tabular}

Tabel 10. Keinginan mengikuti pelatihan

\begin{tabular}{|c|c|c|c|c|}
\hline No & Jenis Option & Skor Jawaban & Persentasi & Kualifikasi \\
\hline 1 & Tidak Pernah & 41 & $28 \%$ & Sangatn Rendah \\
\hline 2 & Pernah & 37 & $26 \%$ & Rendah \\
\hline 3 & Jarang & 22 & $17 \%$ & Sedang \\
\hline 4. & Selalu & 44 & $29 \%$ & Tinggi \\
\hline
\end{tabular}

Berdasarkan aspek materi TIK sesuai Kurikulum Pelatihan yang disusun oeh Pusdiklat Teknis jakarta, dapat dilihat bahwa kompetensi guru dalam pemanfaatan TIK pada pembelajaran sangat rendah pada materi pada aspek kompetensi pemanfaatan prezzy sebagai aplikasi menarik dalam pembelajaran dengan nilai $68 \%$. Level kompetensi terendah berikutnya adalah kompetensi guru dalam pemanfaatan blog sebagai portofolio guru dalam pembelajaran dengan nilai $50 \%$. Berikutnya adalah aspek kompetensi pemanfaatan video dalam pembelajaran dengan nilai $47 \%$ dan yang terakhir adalah aspek kompetensi pemanfaatan Google Classroom dalam pembelajaran daring dengan nilai $28 \%$.

Berdasarkan indikator yang telah dijabarkan ke dalam instrumen penelitian, maka indikator yang sangat rendah terdapat pada kemampuan guru menggunakan dan memanfaatkan aplikasi sebesar $52 \%$. Persentasi yang sangat seimbang juga terdapat pada indikator pengalaman guru mengikuti pelatihan yang terkait dengan teknologi informasi dan komunikasi yaitu sebesar $57 \%$.

\section{SIMPULAN}

Dari tabel hasil pengolahan data angket yang telah dipaparkan di atas, maka dapat disimpulkan bahwa kompetensi guru MIN 4 Kabupaten Langkat dalam pemanfaatan Teknologi Informasi dan Komunikasi berdasarkan ukuran kurikulum pelatihan TIK yang di susun oleh Pusdiklat Teknis Keagamaan, secara umum masih dapat dikategorikan pada posisi sangat rendah.

Selanjutnya, dari data yang telah dipaparkan pada bab pembahasan, dapat disimpulkan bahwa terdapat hubungan yang sangat signifikan antara rendahnya kompetensi guru MIN 4 Langkat dalam pemanfaatan TIK pada pembelajaran dengan pengalaman guru dalam mengikuti pelatihan dengan besaran presentasi yang sama-sama sebesar $50 \%$. Hal ini menunjukkan bahwa kegiatan pelatihan 
sangat dibutuhkan guru dalam rangka meningkatkan kompetensinya dalam memanfaatkan TIK pada pembelajaran. (Warsihna, 2014). Pelatihan pemanfaatan TIK sangat penting bagi para guru agar tercipta pembelajaran yang menarik sehingga siswa dapat berperan aktif di dalam pembelajaran. (Waldopo, 2015).

\section{SARAN}

Namun demikian, paparan hasil analisis data dalam penelitian ini masih memerlukan penelusuran lebih mendalam karena paparan analisis data ini masih di telaah secara kuantitatif. Belum diketahui secara kualitatif kompetensi dan permasalahan -permasahan guru MIN 4 Langkat terkait dengan teknologi informasi dan komunikasi, sejauh mana tingkat pemahaman dan faktor-faktor yang menyebabkan rendahnya kompetensi tersebut. Oleh sebab itu perlu penelitian lebih lanjut terkait dengan kompetensi guru khususnya guru MIN 4 Langkat dalam pemanfaatan teknologi informasi dan komunikasi pada pembelajaran.

\section{DAFTAR PUSTAKA}

Andina, E. (2018). Efektivitas Pengukuran Kompetensi Guru. Aspirasi, 208.

Annisa Zikri Rabbia, Husnul Fuadi. (2020). Pengembangan Keterampilan Multi Media Interaktif Pembelajaran IPA untuk Meningkatkan Literasi Sains Peserta Didik di Abad 21. Jurnal IImiah Profesi Pendidikan, 119.

Anugrahana, A. (2020). Hambatan, Solusi dan Harapan : Pembelajaran Daring selama masa pandemi Covid -19 Guru Sekolah Dasar. Scholaria : Jurnal Pendidikan dan Kebudayaan Vol.10 No.3, 283.
Anugrahana, A. (2020). Hambatan, Solusi dan Harapan : Pembelajaran Daring Selama Masa Pandemi-Covid-19 Oleh Guru Sekolah Dasar. Scholaria, Jurnal Pendidikan dan Kebudayaan Vol. 10 No. 3, 283.

Anugrahana, A. (2020). HAmbatan, Solusi, dan Harapan : Pembelajaran Daring Selama Pandemi Covid-19 Oleh Guru Sekolah Dasar. Scholaria, Jurnal Pendidikan dan Kebudayaan Vol.10 No. 3, 283.

Idris , Fauzan. (2018). Penggunaan Teknologi Informasi dan Komunikasi dalam Pembelajaran oleh Guru Pendidikan Agama Islam. Jurnal Riset dan Kajian Pendidikan Agama Islam, 98.

Indonesia, K. B. (2021, Oktober Jumat). kbbi.web.id. Retrieved from https://kbbi.kemdikbud.go.id/: https://www.kbbi.web.id/kompetensi

Isradini, dkk. (2020). Peran Teknologi Informasi dan Komunikasi Pada Pembelajaran Daring Di Masa Pandemi Covid-19. Jurnal Perseda Volume 3, Nomor 3, 177.

Ita Rahmadani, dkk. (2021). Kreativitas Guru Berprestasi Dalam Pemanfaatan Media Pembelajaran di Madrasah Ibtidaiyah Negeri 2 Banda Aceh. Jurnal IImiah Didaktika, 8.

Ita Rahmadani, Lailatussaadah, Cut Nya Dhin, Salma Hayati. (2021). Kreativitas Guru Bersertifikasi Dalam Pemanfaatan Media Pembelajaran di Madrasah Aliyah Negeri 2 ( MIN Banda Aceh) . Jurnal IImiah Didaktika Vol.21 No.2, 8.

Karjani. (2019). Peningkatan Kompetensi Guru Dalam Pembelajaran Berbasis Multi Media Interaktif Melaui In 
Hause Training di SD Negeri 1 Giriwoyo. Elementary School, 115.

Keagamaan, P. T. (2021). Kurikulum dan Silabus Pelatihan Teknis Pendidikan dan Keagamaan. In Struktur Program Pelatihan TIK MTS (p. S.P.G.15). Jakarta: Pusdiklat Teknis Keagamaan.

Kebudayaan, K. P. (2013). Paparan Pengembangan Kurikulum 2013. Jakarta: Kemendikbud.

Kemendiknas. (2007). Standar Kompetensi Tenaga Pendidik dan Tenaga Kependidikan. Jakarta: Kemendiknas.

Kemendiknas. (2007). Standar Kualifikasi Tenaga Pendidik dan Kependidikan. Jakarta: Kemendiknas.

Kemendiknas. (2016). Standar Kompetensi Tenaga Pendidik dan Kependidikan. Jakarta: Kemendiknas.

Makruf, I. (2020). Pemanfaatan Teknologi Informasi dan Komunikasi Dalam Pembelajaran Bahasa Arab di Madrasah Aliyah Kabupaten Sukoharjo. Journal of Arabic Studies 5 (1) , 83.

Mulyana. (2019). Pemanfaatan TIK Dalam Pembelajaran ( Studi Kasus Di Madrasah Aliyah Negeri I Bandung Barat. Penamas Volume 32 Nomor 1 Januari-Juni, 550.

Nadya isradini, dkk. (2020). Peran Teknologi Informasi dan Komunikasi Pada Pembelajaran Daring Di Masa Pandemi Covid-19. Jurnal Perseda Volume 3, Nomor 3, 177.

Permendiknas. (2021, Nopember Jumat). Permendiknas No 16 Tahun 2007 Tentang Standar Kualifikasi Akademik dan Kompetensi guru . Retrieved from
Among

Guru:

https://www.amongguru.com

Propinsi Sumatera Utara, K. K. (2020). Statistik. Medan: Kantor Wilayah Kementerian Agama Propinsi Sumatera Utara.

Puspita, S. L. (2019). Konsep Pembelajaran Daring Ditengah Pandemi Covid 19 . Equivalent: Jurnal IImiah Sosial Teknik Vol.1 No 2.

Rahmadani, dkk. (2021). Kreativitas Guru Berprestasi Dalam Pemanfaatan Media Pembelajaran di Madrasah Ibtidaiyah Negeri 2 Banda Aceh. Jurnal IImiah Didaktika, 8.

Rahmawati, d. (2020). Analisis Pembelajaran Daring Saar Pandemi di Madrasah Ibtidaiyah . Sittah: Journal of Primary Education Vol.1 No.2, 141.

Rivalina, R. (2014). Kompetensi Teknologi Informasi dan Komuinikasi Guru dalam Peningkatan Kualitas Pembelajaran. jurnal Teknodik Vol.18nomor 2, 167.

Rupiah. (2021). Evaluasi Pelaksanaan Pembelajaran Daring dalam masa Pandemi COVID 19 Pada Tingkat Madrasah di Kabupaten Bengkulu Tengah. Sang Pencerah : Jurnal IImiah Unversitas Muhammadiyah Buton Volume 7 No. 2, 182.

Sari, L. P. (2019). Konsep Pembelajaran Daring di Tengah Pandemi Covid 19. Jurnal Ilmiah Sosial Teknik.

Siahaan, S. (2015). Pemanfaatan Teknologi Informasi dan Komunikasi Dalam Pembelajaran : Peluang, Tantangan, dan Harapan. Jurnal Teknodik Vol.19Nomor 3, Desember, 328. 
Suryadi, S. (2015). Peranan Perkembangan Teknologi Informasi dan Komunikasi Dalam Kegiatan Pembelajaran dan Perkembangan Dunia Pendidikan . Jurnal IImiah AMIK Labuhan Batu Vol 3, Nomor 3, 17.

Waldopo. (2015). Dampak Pelatihan Pemanfaatan TIK (PeTIK) Untuk Pembelajaran Bagi Guru di Sekolah Indonesia di Luar Negeri (Studi GuruGuru Indonesia di Bangkok-Thailand). Jurnal Teknodik Vol.19-Nomor 1, April, 32.
Warsihna, J. (2014). Peranan TIK Dalam Pembelajaran di Sekolah Dasar Sesua Kurikulum 2013. Jurnal Teknodik, Vol.18, Nomor 2 Agustus, 164.

Yunitasari, d. (2016). Studi analisis Kompetensi Paedagogik Guru Pendidikan Kewarganegaraan Dalam Penguasaan Media Pembelajaran Berbasis Teknologi Informasi dan Komunikasi pada SMP Negeri di Kecamatan Selogiri. PKn Progresif , 449. 